$11-1-2005$

\title{
Barnacles, old age marks, or just plain seborrheic keratoses.
}

\author{
Lawrence Charles Parish \\ Thomas Jefferson University \\ Joseph A. Witkowski \\ University of Pennsylvania
}

Follow this and additional works at: https://jdc.jefferson.edu/dcbfp

Part of the Dermatology Commons

\section{Let us know how access to this document benefits you}

\section{Recommended Citation}

Parish, Lawrence Charles and Witkowski, Joseph A., "Barnacles, old age marks, or just plain seborrheic keratoses." (2005). Department of Dermatology and Cutaneous Biology Faculty Papers. Paper 122.

https://jdc.jefferson.edu/dcbfp/122

This Article is brought to you for free and open access by the Jefferson Digital Commons. The Jefferson Digital Commons is a service of Thomas Jefferson University's Center for Teaching and Learning (CTL). The Commons is a showcase for Jefferson books and journals, peer-reviewed scholarly publications, unique historical collections from the University archives, and teaching tools. The Jefferson Digital Commons allows researchers and interested readers anywhere in the world to learn about and keep up to date with Jefferson scholarship. This article has been accepted for inclusion in Department of Dermatology and Cutaneous Biology Faculty Papers by an authorized administrator of the Jefferson Digital Commons. For more information, please contact: JeffersonDigitalCommons@jefferson.edu. 


\title{
Barnacles, Old Age Marks, or Just Plain Seborrheic Keratoses
}

\author{
Lawrence Charles Parish, M.D.
}

Department of Dermatology and Cutaneous Biology, Jefferson Medical College of Thomas Jefferson University and Editor-in-Chief

\author{
Joseph A. Witkowski, M.D. \\ Department of Dermatology, University of Pennsylvania \\ School of Medicine
}

Growing older may mean more wrinkles and creaking joints, but why does it also entail an accumulation of barnacles. These brown, somewhat friable, often warty lesions are more common on senior citizens but are not necessarily limited to the chronologically challenged. Seborrheic keratoses (SKs) can be easily recognized (fig 1), but the itching and the occasional scratch-induced dermatitis make them more than a cosmetic nuisance. (fig 2)

SKs can go by a variety of names, ranging from basal cell papillomas, senile warts, and senile keratoses to seborrheic verrucae and verrucous senilis. The various terms provide no more information on their natural history or the etiology of these benign lesions, other than that age is somehow associated. (1)

\section{Etiology}


The etiology of the SK is elusive, despite its long time recognition. There is some evidence that the human papillomavirus (HPV) plays a role in its development. $(2,3)$, but Koch's postulates have yet to be fulfilled. Through the use of such current laboratory tools as in situ hybridizations (ISH), polymerase chain reactions (PCR) Southern blot hybridizations, and sequencing of viral DNA of PCR-amplified fragments, HPV has been implicated, particularly types 6 and 18. Unfortunately, we still await final confirmation or disassociation.

The poxvirus associated with molluscum contagiosum and even a herpesvirus have also been found in SK-like lesions(4). To complicate the issue further, actinic keratoses are not alone in being sun-induced, for it seems that patients have more SKs, if they have had many and extensive sunburns. (5)

\section{Clinical Findings}

The traditional SK can vary anywhere in size from a few $\mathrm{mm}$ to a few $\mathrm{cm}$. It rarely appears in younger patients, has no gender preference, and is not found on mucous membranes or the palms and soles. Sometimes, it is flat enough that only the brownish discoloration and possible scaling give its presence away. Other times, it is unevenly elevated and irregularly pigmented to provide the experienced clinician with concern about a possible malignancy, such as melanoma,(6) basal cell carcinoma, or squamous cell carcinoma.(7) Fortunately, the clinical picture of the SK is characteristic enough that a biopsy is infrequently needed.

\section{Established Variations}

\section{Dermatosis papulosa nigra}

First described by Castelanni in 1925, dermatosis papulosa nigra (DPN) (fig 2) is found in black patients, predominantly women past thirty, who have their roots in the Caribbean or Central America. A DPN is a small, darkly-colored, elevated lesion that can be clustered, most often on the face. Although these nuisances were once considered to be hereditary in origin, the histopathology suggests that a DPN is little different from an ordinary SK. (8)

\section{$\underline{\text { Stucco keratosis }}$}

The stucco keratosis (fig 3) is usually found on the legs of older men, often in association with xerosis. It is white to gray with some scaling, giving the appearance that it was glued onto the skin as an after thought. When removed, there is little to no bleeding. (9)

\section{$\underline{\text { Sign of Leser-Trélat }}$}

The sign of Leser-Trélat has created another enigma, since it inception a century ago. Does the sudden onset of many SKs indicate an underlying malignancy? Again, carcinomas occur in older patients, and older patients have SKs. While this finding may 
be considered a paraneoplastic sign, the correlation has come under attack.(10) A similar situation occurred a few decades ago with herpes zoster, when it is diagnosed in older patients who also have malignancies.

\section{Conclusions}

SKs and their variations are not destructive, so the question arises about intervening. They sometimes disappear of their own accord and treatment has little risk, whether the approach is surgical (snipping, curettage, electrodessication, cryosurgery, etc. or chemical (salicylic acid, trichloracetic acid, aquaglycolic acid, etc.).

When do we intervene? 1) When the itching and secondary dermatitis become problems, the lesion(s) should be eliminated. 2) When the patient or special other has concerns about cancer and reassurance does not eliminate the doubt, the $\mathrm{SK}(\mathrm{s})$ should be removed. 3) When this benign lesion catches on clothing or jewelry, intervention is in order. Lastly, 4) when the peers of the patient or the grandchildren continue to fret about the barnacles, it is time to do something.

\section{References:}

1. Ingram JT. The seborrheic diathesis. AMA Arch Dermatol 1957; 76:157-61.

2. Forslund O, Lindelof B, Hradil E, et al. High prevalence of cutaneous human papillomavirus DNA on the top of skin tumors but not in "Stripped" biopsies from the same tumors. J Invest Dermatol 2004; 123:388-94.

3. Masini C, Fuchs PG, Gabrielli F, et al. Evidence for the association of human papillomavirus infection and cutaneous squamous cell carcinoma in immunocompetent individuals. Arch Dermatol 2003; 139:890-4.

4. Googe PB, King R. Herpesvirus infection of seborrheic keratoses. Am J Dermatopathol 2001; 23:146-8.

5. Kwon OS, Hwang EJ, Bae JH, et al. Seborrheic keratosis in the Korean males: causative role of sunlight. Photodermatol Photoimmunol Photomed 2003; 19:73-80.

6. Thomas I, Kihiczak NI, Rothenberg J, Ahmed S, Schwartz RA. Melanoma within the seborrheic keratosis. Dermatol Surg 2004; 30:559-61.

7. Maize JC, Snider RL. Nonmelanoma skin cancers in association with seborrheic keratoses. Clinicopathologic correlations. Dermatol Surg 1995; 21:960-2.

8. Hairston MA, Jr., Reed RJ, Derbes VJ. Dermatosis papulosa nigra. Arch Dermatol 1964; 89:655-8.

9. Willoughby C, Soter NA. Stucco keratosis. Arch Dermatol 1972; 105:859-61.

10. Farrell AM, Dawber RP. Sign of Leser-Trelat. J Am Acad Dermatol 1997;37:1389.

Fig. 1 Seborrheic keratoses

Fig. 2 Seborrheic keratoses with irritant dermatitis 
Fig. 3 Dermatosis papulosa nigra

Fig. 4 Stucco keratoses (note choice of two pictures) 